\title{
Benefits of Levonorgestrel Intrauterine Device Use vs. Oral or Transdermal Progesterone for Postmenopausal Women Using Estrogen Containing Hormone Therapy
}

Kaylee Clark, PharmD student; Sarah M. Westberg, PharmD, FCCP, BCPS

University of Minnesota College of Pharmacy

\begin{abstract}
Background: Endometrial hyperplasia is a major concern for women that start estrogen replacement therapy (ERT) to control symptoms experienced during perimenopause and postmenopause. Progesterone provides protection against endometrial hyperplasia, and there are multiple dosage forms of progesterone available. Intrauterine progesterone may offer an appealing option with additional benefits beyond endometrial protection for patients.

Objective: The overarching objective of this systematic review is to characterize the relationship between levonorgestrel containing intrauterine devices (LNG-IUD) and the prevention of endometrial hyperplasia in peri- and postmenopausal women. Specifically, this systematic review addresses whether LNG-IUD has equivalent efficacy of protecting against endometrial hyperplasia, but an improved safety profile when compared to oral progesterone in women using ERT.

Methods: OVID Medline, Scopus, and Cochrane were used to find available studies that have investigated the relationship between endometrial hyperplasia prevention and varying dosage forms of progesterone. Randomized control studies comparing LNG-IUD with no treatment, placebo, or other hormonal therapy in adult females were included. In addition, due to a lack of randomized control studies, four non-comparative studies were included.

Results: There were eleven total studies included that investigated LNG-IUD use in women on ERT. According to the studies, the LNGIUD was equally effective as other routes (oral, vaginal) of progesterone administration in protecting against endometrial hyperplasia. Conclusions: The LNG-IUD prevents endometrial proliferation at least as effective as oral or vaginal forms of progesterone. LNG-IUD is a safe option for women starting estrogen replacement therapy and has added benefits due to decreased adverse effects.
\end{abstract}

Keywords: hormone therapy, hormone replacement therapy, postmenopausal, levonorgestrel intrauterine device, endometrial hyperplasia

\section{Introduction}

According to the American Cancer Society, cancer of the endometrium has the highest incidence of the female reproductive organs in the United States. ${ }^{1}$ A risk factor of endometrial cancer is endometrial hyperplasia, which is caused by excess proliferation of the endometrium. Unopposed endometrial exposure to estrogen can lead to endometrial hyperplasia or cancer of the endometrium for perimenopausal and postmenopausal women. Estrogen hormone therapy is the most effective treatment for vasomotor symptoms and genitourinary syndrome (GSM), which many women experience during the menopause transition and into the postmenopausal state.

To protect against the proliferation of the endometrium and decrease the risk of developing endometrial hyperplasia or endometrial cancer, progesterone must be added to the estrogen therapy. Traditionally, oral, transdermal, or vaginal progesterone products have been prescribed to protect the endometrial integrity from the effects of systemic estrogen therapy, but these dosage forms are associated with adverse

Corresponding author: Sarah Westberg, PharmD, FCCP, BCPS University of Minnesota College of Pharmacy

Department of Pharmaceutical Care \& Health Systems

Email: swestber@umn.edu side effects. ${ }^{2}$ The North American Menopause Society (NAMS) addresses that non-oral routes of administration, such as intrauterine systems, may offer potential advantages due to bypassing the first-pass hepatic effects and a reduction of side effects caused by systemic progesterone products. $^{2}$ Levonorgestrel Intrauterine Device (LNG-IUD) provides additional benefits including contraception for women in perimenopause, increases compliance, effectively manages bleeding problems during the transition from peri-menopause to postmenopause, and may increase quality of life. There is some evidence that the addition of progesterone containing LNG-IUD to estrogen hormone therapy has equal efficacy in preventing endometrial hyperplasia, by conversion of the anovulatory endometrium into an atrophic endometrium with infrequent, light bleeding. ${ }^{3}$ More importantly, the use of LNGIUD for women on estrogen therapy may decrease toxicities and medication burden. In addition to providing contraception for perimenopausal women and managing bleeding events, there are other benefits of LNG-IUD over systemic exposure. Common adverse effects of systemic progesterone therapy are breast tenderness, edema, mood changes, and weight gain. However, with LNG-IUD a lower dose is used due to direct exposure in the uterus; systemic exposure is therefore minimized and the common side effects associated with progesterone are reduced. ${ }^{4}$ 


\section{Methods}

The methods section followed the Preferred Reporting Items for Systematic Review and Meta-Analyses (PRISMA) checklist as closely as possible. ${ }^{5}$ The Patient, Intervention, Control, and Outcome parameters (PICO) of this systematic review were as follows: The patient population included are perimenopausal and postmenopausal women on estrogen replacement therapy with an intact uterus. The intervention was levonorgestrel intrauterine device. The comparison or control was patients on either oral, transdermal, or vaginal forms of progesterone therapy, which are the current standard of care. The exception to this were four non-comparative studies. The outcomes included were endometrial hyperplasia incidence, excessive uterine bleed events and incidence of adverse drug reactions. In addition, the number of participants that were excluded from the study was reported. These outcomes were specifically chosen because each one evaluates the efficacy of the levonorgestrel intrauterine device being an equivalent substitute for oral, transdermal, or vaginal progesterone products for preventing endometrial hyperplasia in women using estrogen replacement therapy, while also determining the safety profiles of different routes of administration.

The inclusion criteria were randomized control studies comparing LNG-IUD with no treatment, placebo, or other hormonal therapy in adult females, case control studies, and non-comparative studies in English. The design of the review was broad due to the limitation of data available. Any patient population that was in perimenopause or postmenopause was included, unless one of the exclusion criteria fit. The exclusion criteria were expert opinion publications and review articles, and studies that examined women already diagnosed with endometrial hyperplasia, endometrial cancer, or any other disease of the uterus. Subjective based studies were included to evaluate the safety profile of LNG-IUD use. Some of the side effects evaluated were less measurable and data was based on the patients' qualitative responses (i.e. vasomotor symptom relief).

The search engines utilized were Ovid Medline, Cochrane, and Scopus. The basic search terms included were levonorgestrel, intrauterine devices, endometrium and endometrial hyperplasia. The search of Ovid Medline was between January $1^{\text {st }} 1960$ - April $16^{\text {th }}, 2018$. The search was limited to 1960 or later, because the use of estrogen replacement therapy nearly doubled between 1960 and $1975 .^{6}$ Cochrane and Scopus were searched with similar key terms. Another strategy for finding studies and additional information was by looking through the references of studies that were identified and included in this review. Please see Appendix A for a detailed outline of the Ovid Medline, Cochrane, and Scopus search strategies used. A librarian at the University of Minnesota Biomedical Library was consulted to suggest appropriate search engines to use for the research question and to validate the search algorithm carried out.

\section{Study selection and data extraction}

After identifying an initial list of studies based on the search criteria, it was further narrowed down by the inclusion and exclusion criteria listed above. The studies that were not rejected based on the abstract and title were read in full to determine eligibility based on the inclusion and exclusion criteria by one author (KC). While analyzing each paper the references of some articles were used to find additional studies that potentially fit the criteria of the systematic review. Key components from the studies were chosen and synthesized (see Table 1).

\section{Quality of evidence and risk of bias in individual studies}

The articles were methodologically appraised using the checklist on the Critical Appraisal Skills Programme (CASP) criteria to determine quality and risk of bias ${ }^{7}$ (see Table 2). In the end, the articles were categorized as "high", "moderate" or "low" according to the analysis of each study (see Table 2). The Cochrane risk of bias tool was used to evaluate the bias of each study $^{8}$ (see Table 3). There were four studies included that were not randomized controlled studies, but rather non-comparative prospective study so there was inherent bias within those studies.

\section{Results}

From the three search engines used, 160 potential studies were identified using the search terms described above, but 13 were removed as duplicates. The titles and abstracts were reviewed and 124 studies were removed as a result of not meeting the inclusion/exclusion criteria outlined (see Figure 1). The full text of the remaining 23 studies were assessed. Figure 1 includes the rationale for exclusion of 12 articles. References of the studies found were also investigated for more eligible studies, but none were identified. After going through this process, eleven studies were included in this systematic review.

The eleven studies identified for inclusion were completed within the last 30 years, which has been a time of increased research on perimenopausal and postmenopausal hormone therapy. A majority of the studies selected were randomized control trials, but there were four of the eleven that were noncomparative prospective studies. There is limited data available, so it was determined to be appropriate to include these additional studies. A summary of the characteristics and key findings of the eleven studies can be found in Table 1.

All seven of the randomized control studies selected had a low risk of bias based on the Cochrane Risk of Bias tool. Using the CASP checklist, the quality of the evidence was high and there was a low risk of bias. As expected, the 4 non-comparative studies had a high risk of bias using both tools (see Tables 2 and 3).

A study by Andersson et al. published in 1992 compared 20-mcg levonorgestrel-IUD continuous and $2 \mathrm{mg}$ oral estradiol valerate daily versus a 28-day cycle of $2 \mathrm{mg}$ oral estradiol valerate daily 
for days 1-21 and $250 \mathrm{mcg}$ oral levonorgestrel on days $11-21 .^{9}$ The 40 perimenopausal women enrolled in the study were followed for 1 year, with 3 participants withdrawing from the study. There were 2 women that were excluded due to adverse effects. The main outcomes reported were endometrial histopathology and bleeding patterns. After 12 months, no endometrial hyperplasia was reported in either treatment group. The group in the cyclic treatment continued to have bleeding/spotting for an average of 6 days, whereas the LNGIUD group had $83 \%$ of women become amenorrhoeic after the 12-month study. ${ }^{9}$

A study by Raudaskoski et al. published in 1995 compared continuous 20-mcg levonorgestrel-IUD and 50-mcg transdermal estradiol versus continuous $1 \mathrm{mg}$ oral norethisterone acetate daily and $2 \mathrm{mg}$ oral estradiol valerate daily. ${ }^{10}$ The 40 postmenopausal women enrolled in the study were followed for 1 year, except eight participants that withdrew from the study. Of the eight participants, five withdrew from the LNG-IUD and three withdrew from the comparative group. The main outcomes reported were endometrial histopathology and bleeding patterns. They found no endometrial hyperplasia in either group after 12 months. After 12 months of treatment there was no difference in the bleeding pattern between the groups. There were less progesterone related side effects (headache, breast tenderness, etc.) reported in the LNG-IUD group compared to the other treatment group. ${ }^{10}$

A study done by Antoniou et al. published in 1997 compared 20-mcg levonorgestrel-IUD and 50-mcg estradiol transdermal patch continuously versus $2 \mathrm{mg}$ estradiol vaginal ring continuously and $100 \mathrm{mg}$ vaginal progesterone suppository daily for 7 days every month. ${ }^{11}$ The 56 postmenopausal women were followed for 1 year. The major outcomes followed were endometrial thickness and reported bleeding/spotting by study subjects. There was no evidence of endometrial proliferation in either group. The LNG-IUD group had more bleeding days than the comparative group during the first months of treatment, but by the end the differences were no longer seen. ${ }^{11}$

A study done by Suvanto-Luukkonen et al. compared 20-mcg LNG-IUD in combination with $1.5 \mathrm{mg}$ transdermal estradiol gel (150 mcg/day) versus $1.5 \mathrm{mg}$ transdermal estradiol gel (150 $\mathrm{mcg} /$ day) with $100 \mathrm{mg}$ oral natural micronized progesterone capsules daily OR 100 vaginal progesterone on days 1-25 per month. ${ }^{12}$ There were 12 women in the vaginal progesterone group that had progesterone increased to $200 \mathrm{mg}$ due to abnormal bleeding. The 51 postmenopausal women were followed for 1 year. The major outcome investigated in the study was endometrial responses based on endometrial biopsy. The results showed that LNG-IUD protected the endometrium from proliferation, whereas the dose chosen for the oral and vaginal form of natural progesterone was not sufficient and proliferative features were seen in approximately half of the endometrial specimens. ${ }^{12}$
A randomized control study done by Wollter-Svensson et al. investigated the histopathology of the endometrium and bleeding patterns while using different strengths of LNG-IUD (5mcg or $10-\mathrm{mcg}) .^{13}$ The study was done at two health centersone center started all women $(n=51)$ on $50 \mathrm{mcg} / 24$ hours transdermal estradiol and the other center had women $(n=57)$ start on $2 \mathrm{mg}$ oral estradiol. Then the women were randomized to receive either the 5-mcg or the 10-mcg LNG-IUD. There were 12 women, 6 from each IUD group, that withdrew from the study; 7 of the women that discontinued was a result of bleeding pattern. One women in the study did have a proliferative endometrium after 1 year, but the likely explanation for this is her first IUD was replaced due to expulsion. After 12 months of LNG-IUD insertion, 59 out of 96 women (65\%) reported amenorrhea. ${ }^{13}$

A prospective study done by Raudaskoski et al. published in 2002 compared 20-mcg levonorgestrel-IUD and 2 mg estradiol oral daily versus $2 \mathrm{mg}$ estradiol oral daily and medroxyprogesterone acetate $5 \mathrm{mg}$ on 14 out of 30 days. ${ }^{14}$ There were a total of 109 postmenopausal, European women that were followed for 1 year. The main outcomes investigated were histopathology of the endometrium and bleeding patterns. After 6 months of using the LNG-IUD, 54 out of the 55 women had no bleeding. In contrast, the comparative group continued to have predictable bleeding during the withdrawal time from progesterone. After the completion of the study it was found that all women in the LNG-IUD group had endometrial suppression and no proliferation, whereas the comparative group (medroxyprogesterone) found 18 out of 47 women with proliferation of the endometrium. Therefore, the medroxyprogesterone and estradiol combination did not fully suppress the endometrium. ${ }^{14}$

A study done by Boon et al. compared 20-mcg levonorgestrelIUD combined with $2 \mathrm{mg}$ oral estradiol daily versus the cyclic oral norethisterone $1 \mathrm{mg}$ administered on days 1-22 and oral estradiol $2 \mathrm{mg}$ on days $1-21$, then $1 \mathrm{mg}$ on days $22-28$ of a 28 day cycle. ${ }^{15}$ The main outcomes investigated were endometrial protection and bleeding patterns. No endometrial hyperplasia was found in either group. In this study there were 8 total reference periods, with a reference period defined by 3 of the 28 -day cycles. After the $8^{\text {th }}$ reference period it was found that $62 \%$ of the women in the LNG-IUD group were amenorrhoeic. Whereas, the majority of the comparative cyclic group continued to have normal bleeding patterns. ${ }^{15}$

A non-comparative study done by Wildemeersch et al. published in 2005 investigated the effectiveness of 14 -mcg levonorgestrel IUD and $1.5 \mathrm{mg}$ oral estradiol in perimenopausal and postmenopausal women. ${ }^{16}$ The main outcomes investigated were endometrial safety and patient acceptance. There was a total of 150 women that participated, 94 were perimenopausal and 56 were postmenopausal. There was a total of 8 women that withdrew from the study, and reasons varied from non-compliance, abnormal bleeding and pain 
complaints. No proliferation was found and inactive endometrium was dominant. ${ }^{16}$

A second non-comparative study done by Wildemeersch et al. published in 2007 investigated the effectiveness of $20-\mathrm{mcg}$ LNG-IUD in combination with $1.5 \mathrm{mg}$ oral estradiol daily continuously in suppressing the endometrium from proliferation. ${ }^{17}$ The 102 postmenopausal women were followed for a total of 5 years to determine the endometrial safety of LNG-IUD. The main outcome of the study was endometrial histology. A biopsy and examination of the endometrium was conducted after 3 years (at which time the LNG-IUD was removed and replaced) and again at the conclusion of the study. There were also follow ups with endometrial ultrasound at months 1, 3, 6 and 12 months following the insertion of the IUD and then at 6-month intervals during the 5-year period. A thin endometrium was maintained by all women throughout the entire study. There were two women with weak endometrial proliferative activity, but there were no women with endometrial hyperplasia ${ }^{17}$.

In a similar design, another 5-year non-comparative prospective study was done by Hampton et al. in 2005, looking at 82 perimenopausal women that received oral conjugated equine estrogen (CEE) $1.25 \mathrm{mg}$ daily and 20-mcg LNG-IUD. ${ }^{18}$ The objective was to determine the long-term efficacy of using LNGIUD to protect the endometrium from hyperplasia. Each year endometrial biopsy and histological assessment was conducted. There were 8 women that withdrew due to adverse effects, 1 woman withdrew due to partial expulsion of the IUD, and 7 women discontinued for reasons unrelated to the treatment. The other 5 discontinuations were women that completed the study at 24 months but did not wish to continue with the extension of the study. No endometrial hyperplasia was found at the end of the 60-month study. Vasomotor symptoms (hot flushes, sweating, and vaginal discomfort) all improved significantly during the first 2 years of treatment. For instance, $35.4 \%$ of women at the study entry reported no hot flushes and after 6 months, 84.4\% reported no hot flashes. In addition, vaginal bleeding was reported through the study participants recording in a 'bleeding diary'. Amenorrhea was reported in $54.3 \%$ of women during reference period $6^{\mathrm{a}}$ and $85.4 \%$ during the final reference period. ${ }^{18}$

A follow-up study done by Varila et al. studied the effects of replacing the LNG-IUD after 5 years of use when used for ERT and how endometrial histology is affected. ${ }^{19}$ Initially, there were 40 women enrolled in the 12-month study that started ERT with 20-mcg LNG-IUD and either 50 mcg transdermal or 2 $\mathrm{mg}$ oral estradiol; 39 women finished the 12 months of treatment. All participants that finished the 12 months had no evidence of endometrial hyperplasia and 25 (64\%) women were amenorrheic. The women were permitted to continue ERT with the LNG-IUD and estrogen of choice for 5 years. After 5 years had passed there were 32 women still using LNG-IUD and 29 of the women consented to participate in the follow-up study where the LNG-IUD would be replaced with a new one. Of the 29 women, there was no evidence of endometrial hyperplasia after 5 years of LNG-IUD treatment. At 3 months post reinsertion of the new LNG-IUD, 5 women were amenorrheic and the median number of spotting days was $3 .{ }^{19}$

\section{Discussion}

All seven of the RCT's demonstrated that none of the participants in the LNG-IUD group developed endometrial hyperplasia while on ERT. ${ }^{9-15}$ Furthermore, the four noncomparative studies had a combined total of 351 women (154 perimenopausal and 197 postmenopausal) that did not have endometrial proliferation. ${ }^{16-19}$ This suggests that the LNG-IUD has no additional safety risks in regard to endometrium protection, when comparing to other dosage forms of progesterone (oral and vaginal). Although the risk of bias is higher with the inclusion of the four non-comparative trials ${ }^{16-19}$, the endometrial safety results are consistent across all of the studies reviewed. ${ }^{9-19}$

It is important to compare the medications and strengths used in the studies to the current commercially available hormone preparations in the United States to gauge the quality and relevance of the studies investigated. Some examples of products available are: conjugated estrogens, estradiol, medroxyprogesterone acetate, and micronized progesterone. ${ }^{2}$ In addition, there are multiple ways to dose hormone therapy, including continuous or cyclic, and via multiple routes of administration, including oral, transdermal, or vaginal. When comparing the commercially available products to the selected studies, the dosing regimens appear appropriate and similar to current clinical practice, with the exception that vaginal progesterone for endometrial protection is not widely used in clinical practice. For the study which used natural progesterone compared to LNG-IUD, the LNG-IUD group was successful in suppressing proliferation of the endometrium, but the comparative group that received either $100 \mathrm{mg}$ or $200 \mathrm{mg}$ of natural progesterone (oral or vaginal) had a clinically significant number of women that had endometrial proliferation. Since the estrogen used in this study was an estradiol gel $1.5 \mathrm{mcg}$ daily, it is unclear if the dose of estrogen was too high or if the progesterone dose or route was inadequate to provide protection. ${ }^{12}$

Additionally, if we look at the bleeding patterns that were monitored in multiple studies we can compare differences in the dosage forms. Two of the studies found that there were similar bleeding events between the two treatment groups after 12 months of treatment. Although in both of the studies, there was more frequent spotting during the first three months of treatment with the LNG-IUD. ${ }^{10,11}$ Three of the randomized control studies saw less bleeding in the LNG-IUD group than the comparative group, though this was likely due to the cyclic progesterone used in the comparative groups which led to predictable withdrawal bleeding. ${ }^{9,14,15}$ One study found after six months of treatment that $98.2 \%$ of postmenopausal women 
had no bleeding in the LNG-IUD group, whereas all postmenopausal women in the cyclical medroxyprogesterone group had withdrawal bleeding. ${ }^{14}$ This suggests that LNG-IUD as a progesterone dosage form when concomitantly used with estrogen replacement therapy may be a superior option for women that would prefer no bleeding or spotting while on treatment, though continuous dosing of oral progesterone may achieve similar outcomes of no bleeding. Another important point to consider is the strength of levonorgestrel used in the treatment. The study that investigated use of 5-mcg and 10mcg LNG-IUD, instead of the higher strength (20-mcg), found the proportion of women with bleeding/spotting during the first three months of therapy is slightly higher and the proportion of women with amenorrhea at 1 year is lower when compared to studies utilizing 20-mcg LNG-IUD. ${ }^{13}$ It is therefore possible that the higher dose of LNG may be more favorable in respect to bleeding patterns.

The last outcome addressed in the PICO was the frequency of adverse side effects associated with progesterone therapy. As a result of this data being subjective, it was more difficult to determine if one treatment group was superior to the other in regard to adverse side effects. All of the selected studies found a reduction in the vasomotor symptoms, ${ }^{9-17}$, but not all investigated the frequency of progesterone related side effects in the results. In one of the non-comparative studies there were no side effects (breast tenderness, headaches, bloating, etc.) related to LNG-IUD reported. ${ }^{16}$ In another study no women in the LNG-IUD group complained of symptoms related to progesterone delivery, but one participant receiving oral progesterone withdrew due to headaches and two others in this group reported breast tenderness. ${ }^{10}$ Whereas, in another study one woman receiving LNG-IUD discontinued due to headaches and breast tenderness. ${ }^{18}$

One of the benefits of LNG-IUD is contraception during perimenopause. Four of the studies chosen included perimenopausal women and there were no exclusions for pregnancy. ${ }^{9,15,16,18}$ One study stated, that although not designed to evaluate contraception efficacy, many of the women relied on the IUD for contraception; during the 318 woman years of exposure no conceptions occurred to the study treatment. ${ }^{18}$ This suggests that the LNG-IUD successfully provided contraception for women transitioning from perimenopause to menopause, while decreasing bothersome vasomotor symptoms through safe use of ERT.

\section{Limitations}

A thorough search was done by using the above strategy outlined in the methods, but it is possible bias may exist due to the chance that some data was unpublished or not uncovered based on the terms used. One weakness of all the studies investigated is the difficulty in blinding participants to use of LNG-IUD, because inserting the LNG-IUD is a procedure that would not be possible to blind. In addition, it would be hard to blind the reviewers and clinicians for the same reason.
Furthermore, there may be some scrutiny based on the publication date of the studies evaluated.

The use of LNG-IUD has proven to provide equivalent protection of the endometrium when estrogen replacement therapy is used during perimenopause and postmenopause for women. The studies examined show similar findings of available research on the use of LNG-IUD in preventing endometrial hyperplasia while women are taking estrogen. None of the studies investigated found that the LNG-IUD was superior to other dosage forms, but all did find equal efficacy in protecting the uterus from endometrial hyperplasia. The possibility of amenorrhea while using LNG-IUD is high, so this is a major rationale of using the intrauterine device over oral forms of progesterone that may be cyclical. There is a need for more research, such as a randomized controlled trial with a large sample size and full evaluation of adverse effects to conclude the added benefits of LNG-IUD over other dosage forms.

Protecting the uterus for women on ERT is essential in preventing endometrial hyperplasia. Although it appears that LNG-IUD is efficacious in protecting against proliferation of the endometrial, it is too soon to definitively conclude that LNG-IUD protects against the development of cancer that is linked to some forms of endometrial hyperplasia. This systemic review did not focus on the development of cancer as it relates to ERT and progesterone dosage forms.

\section{Conclusion}

The result of this literature review has found that LNG-IUD is a safe dosage form option when combined with ERT and may be clinically superior to other progesterone dosage forms (oral, vaginal) in regard to side effect profile and additional benefits, such as contraception for women in peri-menopause, increased compliance, and improved management of bleeding during menopause. The selected studies illustrate that LNG-IUD is no less effective at suppressing endometrial proliferation when compared to other dosage forms, but the studies lack data showing superiority. In theory the LNG-IUD should have increased benefits due to its minimal systemic exposure, added contraception for peri-menopausal women, and ensures compliance by delivering a consistent amount of progesterone to the body. More research is needed to firmly confirm this conclusion.

\author{
Acknowledgements: None \\ Funding/Support: None \\ Conflicts of Interest: None
}




\section{References}

1. American Cancer Society. (2019, March 27). Key Statistics for Endometrial Cancer. Retrieved from: https://www.cancer.org/cancer/endometrialcancer/about/key-statistics.html. Last accessed April 22, 2019.

2. The North American Menopause Society. (2017). The 2017 hormone therapy position statement. Menopause, 24(7), 728-753. DOI: 10.1097/GME.0000000000000921.

3. Fraser, I. (2013). Added health benefits of the levonorgestrel contraceptive intrauterine system and other hormonal contraceptive delivery systems. Contraception, 87(3), 273-279. DOI: 10.1016/j.contraception.2012.08.039.

4. Depypere, H., \& Inki, P. (2015). The levonorgestrelreleasing intrauterine system for endometrial protection during estrogen replacement therapy: a clinical review. Climacteric, 18(4), 470-82. DOI: 10.3109/13697137.2014.991302.

5. Moher, D., Liberati, A., Tetzlaff, J., Altman, D. (2009). Preferred Reporting Items for Systematic Reviews and Meta-Analyses: The PRISMA Statement. Annals of Internal Medicine, 6(7), 264-269. DOI:10.1371/journal.pmed100009

6. Watkins, E. (2007). The estrogen elixir: a history of hormone replacement therapy in America. Baltimore, MD: John Hopkins University Press.

7. Critical Appraisal Skills Programme (2018). Modified CASP (Systematic Review) Checklist. [online] Retrieved from: https://casp-uk.net/wpcontent/uploads/2018/01/CASP-Systematic-ReviewChecklist_2018.pdf. Last accessed June 9, 2019.

8. Higgins JPT, Savovic J, Page MJ, Sterne JAC. Revised Cochrane Risk of Bias tool for randomized trials (RoB2). March 15, 2019. Available at: https://drive.google.com/file/d/1pbkUAco17DolVziiVeU TuvaBME7dACmD/view. Last accessed June 10, 2019.

9. Andersson, K., Mattsson, L.A., Rybo, G., Stadberg, E.. (1992). Intrauterine release of levonorgestrel--a new way of adding progestogen in hormone replacement therapy. The American College of Obstetrician \& Gynecologists, 79(6): 963-967.

10. Raudaskoski, H., Lahti, E.I., Kauppila, J., Apaja-Sarkkinen, A. (1995). Transdermal estrogen with a levonorgestrelreleasing intrauterine device for climacteric complaints: Clinical and endometrial responses. American Journal of Obstetrics \& Gynecology, 172(1): 114-119.

11. Antoniou, G., Kalogirou, D., Karakitsos, P., Antoniou, D., Kalogirou, O., Giannikos, L. (1997). Transdermal estrogen with a levonorgestrel-releasing intrauterine device for climacteric complaints versus estradiolreleasing vaginal ring with a vaginal progesterone suppository: clinical and endometrial responses. Maturitas, 26(2): 103-11.
12. Suvanto-Luukkonen, E., Malinen, H., Sundström, H., Penttinen, J., Kauppila, A. (1998). Endometrial morphology during hormone replacement therapy with estradiol gel combined to levonorgestrel-releasing intrauterine device or natural progesterone. Acta Obstetricia et Gynecologica Scandinavica, 77(7):758-63.

13. Wollter-Svensson, L., Stadberg, E., Andersson, K., Mattsson, L., Odlind, V., Persson, I. (1997). Intrauterine administration of levonorgestrel 5 and $10 \mathrm{mcg} / 24$ hours in perimenopausal hormone replacement therapy. Acta Obstet Gynecol Scand, 76: 449-454.

14. Raudaskoski, T., Tapanainen, J., Tomas, E., Luotola, H., Pekonen, F., Ronni-Sivula, H., Timonen, H., Riphagen, F., Laatikainen, T. (2002). Intrauterine $10 \mathrm{mcg}$ and $20 \mathrm{mcg}$ levonorgestrel systems in postmenopausal women receiving oral estrogen replacement therapy: clinical, endometrial and metabolic response. International Journal of Obstetrics and Gynaecology, 109:136-44.

15. Boon, J., Scholten, P.C., Oldenhave, A., Heintz, A.P. (2003). Continuous intrauterine compared with cyclic oral progestin administration in perimenopausal HRT. Maturitas, 46, 69-77. DOI: 10.1016/S03785122(03)00163-4

16. Wildemeersch, D., Janssens, D., Schacht, E., Pylyser, K., de Wever, N. (2005). Intrauterine levonorgestrel delivered by a frameless system, combined with systemic estrogen: Acceptability and endometrial safety after 3 years of use in peri- and postmenopausal women. Gynecological Endocrinology, 20(6): 336-42. DOI: 10.1080/095513590500099156

17. Wildemeersch, D., Pylyser, K., De Wever, N., Pauwels, P., Tjalma, W. (2007). Endometrial safety after 5 years of continuous combined transdermal estrogen and intrauterine levonorgestrel delivery for postmenopausal hormone substitution. Maturitas, 57(2): 205-9. DOI: 10.1016/j.maturitas.2006.11.010.

18. Hampton, N., Rees, M., Lowe, D., Rauramo, I., Barlow, D., Guillebaud, J. (2005). Levonorgestrel intrauterine system (LNG-IUS) with conjugated oral equine estrogen: a successful regimen for HRT in perimenopausal women. Human Reproduction, 20(9): 2653-2660. DOI: 10.1093/humrep/dei085.

19. Varila, E., Walstrom, T., Rauramo, I. (2001). A 5-year follow-up study on the use of a levonorgestrel intrauterine system in women receiving hormone replacement therapy. Fertility and Sterility, 76(5): 969973. DOI:10.1016/S0015-0282(01)02846-1. 
Figure 1. Flow diagram of literature search and selection criteria adapted from PRISMA. ${ }^{5}$

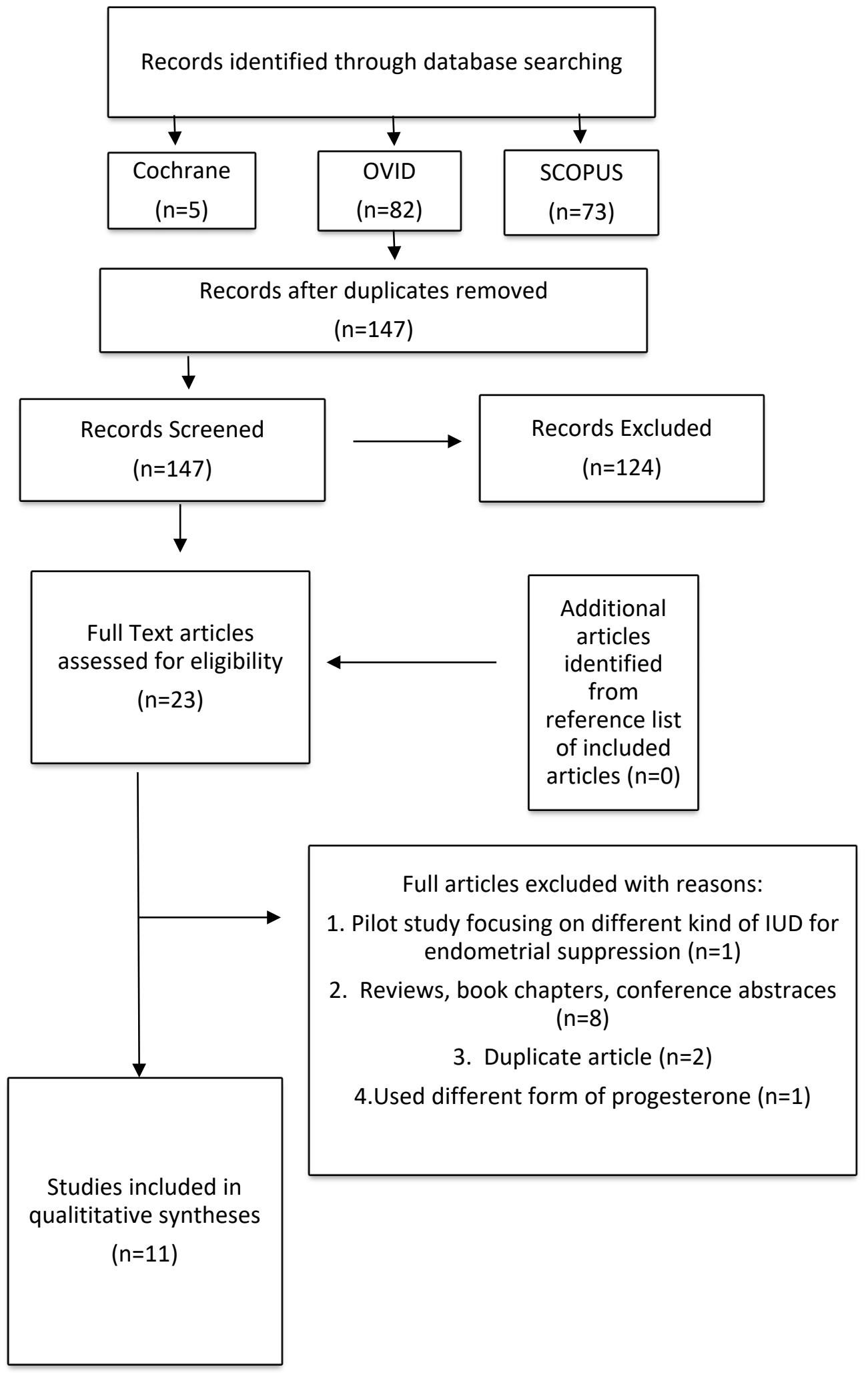


Table 1. Summary of selected studies' characteristics and key findings

\begin{tabular}{|c|c|c|c|c|c|c|c|c|}
\hline Type of study & $\begin{array}{l}\text { First author } \\
\text { (year) }\end{array}$ & $\begin{array}{l}\text { IUD and } \\
\text { estrogen } \\
\text { strength }\end{array}$ & Comparison & No. of subjects & $\begin{array}{l}\text { Treatment } \\
\text { period }\end{array}$ & $\begin{array}{l}\text { Without } \\
\text { bleeding or } \\
\text { spotting } \\
\text { during } \\
\text { treatment } \\
\text { LNG-IUD } \\
\text { group: } \\
\text { Comparison }\end{array}$ & $\begin{array}{l}\text { Endometrial } \\
\text { proliferation } \\
\text { LNG-IUD } \\
\text { group: } \\
\text { comparison }\end{array}$ & $\begin{array}{l}\text { Discontinued } \\
\text { therapy } \\
\text { LNG-IUD group: } \\
\text { comparison }\end{array}$ \\
\hline $\begin{array}{l}\text { Randomized } \\
\text { control trial }\end{array}$ & $\begin{array}{l}\text { Andersson } \\
(1992)^{9}\end{array}$ & $\begin{array}{l}\text { 20-mcg } \\
\text { levonorgestrel- } \\
\text { IUD and } 2 \mathrm{mg} \\
\text { oral estradiol }\end{array}$ & $\begin{array}{l}250 \text { mcg oral } \\
\text { levonorgestrel } \\
\text { (cyclic) and } 2 \mathrm{mg} \\
\text { oral estradiol }\end{array}$ & $\begin{array}{c}40 \\
\text { (perimenopausal) }\end{array}$ & 1 year & $\begin{array}{l}\text { 15/18: 0/19 } \\
\text { after } 12 \\
\text { months }\end{array}$ & $\begin{array}{l}\text { 0/18: 0/19 by } \\
\text { biopsy }\end{array}$ & $2 / 20: 1 / 20$ \\
\hline $\begin{array}{l}\text { Randomized } \\
\text { control trial }\end{array}$ & $\begin{array}{l}\text { Raudaskoski } \\
(1995)^{10}\end{array}$ & $\begin{array}{l}\text { 20-mcg } \\
\text { levonorgestrel- } \\
\text { IUD and 50-mcg } \\
\text { transdermal } \\
\text { estradiol }\end{array}$ & $\begin{array}{l}1 \mathrm{mg} \text { oral } \\
\text { norethisterone } \\
\text { acetate daily and } \\
2 \mathrm{mg} \text { oral } \\
\text { estradiol }\end{array}$ & $\begin{array}{c}40 \\
\text { (postmenopausal) }\end{array}$ & 1 year & $\begin{array}{l}29 \text { days : } 29 \\
\text { days without } \\
\text { bleeding }\end{array}$ & $\begin{array}{l}0 / 15: 0 / 17 \\
\text { by biopsy }\end{array}$ & $5 / 20: 3 / 20$ \\
\hline $\begin{array}{l}\text { Randomized } \\
\text { control trial }\end{array}$ & $\begin{array}{l}\text { Antoniou } \\
(1997)^{11}\end{array}$ & $\begin{array}{l}\text { 20-mcg } \\
\text { levonorgestrel- } \\
\text { IUD and 50-mcg } \\
\text { estradiol } \\
\text { transdermal } \\
\text { patch }\end{array}$ & $\begin{array}{l}100 \mathrm{mg} \text { vaginal } \\
\text { progesterone } \\
\text { suppository } \\
\text { (cyclic) and } 2 \mathrm{mg} \\
\text { estradiol vaginal } \\
\text { ring }\end{array}$ & $\begin{array}{c}56 \\
\text { (postmenopausal) }\end{array}$ & 1 year & $\begin{array}{l}31 \text { days : } 34 \\
\text { days without } \\
\text { bleeding }\end{array}$ & $\begin{array}{l}0 / 28: 0 / 28 \\
\text { by } \\
\text { ultrasound }\end{array}$ & $0 / 28: 0 / 28$ \\
\hline $\begin{array}{l}\text { Randomized } \\
\text { control trial }\end{array}$ & $\begin{array}{l}\text { Suvanto- } \\
\text { Luukkonen } \\
(1998)^{12}\end{array}$ & $\begin{array}{l}\text { 20-mcg } \\
\text { levonorgestrel- } \\
\text { IUD and } 1.5 \mathrm{mg} \\
\text { transdermal } \\
\text { estradiol }\end{array}$ & $\begin{array}{l}100 \mathrm{mg} \text { oral } \\
\text { natural } \\
\text { micronized } \\
\text { progesterone } \\
\text { capsules OR } 200 \\
\text { mg vaginal } \\
\text { progesterone } \\
\text { and } 1.5 \mathrm{mg} \\
\text { transdermal } \\
\text { estradiol }\end{array}$ & $\begin{array}{c}51 \\
\text { (postmenopausal) }\end{array}$ & 1 year & Not reported & $\begin{array}{l}0 / 18: 0 / 19: \\
0 / 15 \text { by } \\
\text { ultrasound }\end{array}$ & $0 / 18: 0 / 19: 0 / 15$ \\
\hline $\begin{array}{l}\text { Randomized } \\
\text { control trial }\end{array}$ & $\begin{array}{l}\text { Wollter- } \\
\text { Svensson } \\
(1997)^{13}\end{array}$ & $\begin{array}{l}\text { 5-mcg or } 10-\mathrm{mcg} \\
\text { levonorgestrel } \\
\text { IUD and } 50 \mathrm{mcg} \\
\text { transdermal } \\
\text { estradiol }\end{array}$ & $\begin{array}{l}\text { 5-mcg or } 10-\mathrm{mcg} \\
\text { levonorgestrel } \\
\text { IUD and } 2 \mathrm{mg} \\
\text { oral estradiol }\end{array}$ & $\begin{array}{c}108 \\
\text { (perimenopausal) }\end{array}$ & 1 year & $\begin{array}{l}59 / 96 \\
\text { (groups } \\
\text { combined) } \\
\text { amenorrhea } \\
\text { after } 12 \\
\text { months }\end{array}$ & $\begin{array}{l}0 / 45: 1 / 51 \\
\text { (from } \\
\text { transdermal } \\
\text { group) by } \\
\text { ultrasound }\end{array}$ & $6 / 51: 6 / 57$ \\
\hline $\begin{array}{l}\text { Randomized } \\
\text { control trial }\end{array}$ & $\begin{array}{l}\text { Raudaskoski } \\
(2002)^{14}\end{array}$ & $\begin{array}{l}\text { 20-mcg } \\
\text { levonorgestrel- } \\
\text { IUD and } 2 \mathrm{mg} \\
\text { oral estradiol }\end{array}$ & $\begin{array}{l}\text { Medroxyprogest } \\
\text { erone acetate } 5 \\
\mathrm{mg} \text { (cyclic) and } 2 \\
\mathrm{mg} \text { oral estradiol }\end{array}$ & $\begin{array}{c}109 \\
\text { (postmenopausal) }\end{array}$ & 1 year & $\begin{array}{l}54 / 55: 0 / 47 \\
\text { (bleed } \\
\text { during week } \\
\text { off) after } 6 \\
\text { months }\end{array}$ & $\begin{array}{l}0 / 55: 18 / 47 \\
\text { by biopsy }\end{array}$ & $1 / 56: 4 / 53$ \\
\hline $\begin{array}{l}\text { Randomized } \\
\text { control trial }\end{array}$ & Boon $(2003)^{15}$ & $\begin{array}{l}\text { 20-mcg } \\
\text { levonorgestrel- } \\
\text { IUD and } 2 \mathrm{mg} \\
\text { oral estradiol }\end{array}$ & $\begin{array}{l}\text { Norethisterone } \\
\text { and oral } \\
\text { estradiol (cyclic) }\end{array}$ & $\begin{array}{c}200 \\
\text { (perimenopausal) }\end{array}$ & 26 cycles & $\begin{array}{l}29 / 76: 0 / 63 \\
\text { amenorrhea } \\
\text { after } 12 \\
\text { months }\end{array}$ & $\begin{array}{l}0 / 76: 0 / 63 \\
\text { by biopsy }\end{array}$ & $24 / 100: 37 / 100$ \\
\hline $\begin{array}{l}\text { Non } \\
\text { comparative, } \\
\text { prospective } \\
\text { study }\end{array}$ & $\begin{array}{l}\text { Wildemeersch } \\
(2005)^{16}\end{array}$ & $\begin{array}{c}14 \text {-mcg } \\
\text { levonorgestrel } \\
\text { IUD and } 1.5 \mathrm{mg} \\
\text { oral estradiol }\end{array}$ & $\begin{array}{l}\text { No comparative } \\
\text { group }\end{array}$ & $\begin{array}{c}150 \text { ( } 94 \\
\text { perimenopausal } \\
\text { and } 56 \\
\text { postmenopausal) }\end{array}$ & 1 year & Not reported & $\begin{array}{l}0 / 101: N / A \\
\text { by biopsy }\end{array}$ & $8 / 150: N / A$ \\
\hline $\begin{array}{l}\text { Non- } \\
\text { comparative } \\
\text { prospective } \\
\text { study }\end{array}$ & $\begin{array}{l}\text { Wildemeersch } \\
(2007)^{17}\end{array}$ & $\begin{array}{c}20-\mathrm{mcg} \\
\text { levonorgestrel- } \\
\text { IUD and } 1.5 \mathrm{mg} \\
\text { oral estradiol }\end{array}$ & $\begin{array}{l}\text { No comparative } \\
\text { group }\end{array}$ & $\begin{array}{c}102 \\
\text { (postmenopausal) }\end{array}$ & 5 years & Not reported & $\begin{array}{l}0 / 102: N / A \\
\text { by biopsy }\end{array}$ & $0 / 102: N / A$ \\
\hline $\begin{array}{l}\text { Non- } \\
\text { comparative } \\
\text { prospective } \\
\text { study }\end{array}$ & $\begin{array}{l}\text { Hampton } \\
(2005)^{18}\end{array}$ & $\begin{array}{l}\text { 20-mcg } \\
\text { levonorgestrel- } \\
\text { IUD and } 1.25 \mathrm{mg} \\
\text { oral CEE }\end{array}$ & $\begin{array}{l}\text { No comparative } \\
\text { group }\end{array}$ & $\begin{array}{c}82 \\
\text { (perimenopausal) }\end{array}$ & 5 years & $\begin{array}{l}51 / 60 \\
\text { amenorrhea } \\
\text { after } 5 \text { years }\end{array}$ & $\begin{array}{l}0 / 60: \text { N/A by } \\
\text { biopsy }\end{array}$ & $22 / 82: N / A$ \\
\hline $\begin{array}{l}\text { Non- } \\
\text { Comparative } \\
\text { prospective } \\
\text { study }\end{array}$ & Varila $(2001)^{19}$ & $\begin{array}{l}\text { 20-mcg } \\
\text { levonorgestrel- } \\
\text { IUD and } 50 \mathrm{mcg} \\
\text { transdermal } \\
\text { estradiol or } 2 \mathrm{mg} \\
\text { oral estradiol }\end{array}$ & $\begin{array}{l}\text { No comparative } \\
\text { group }\end{array}$ & $\begin{array}{c}40 \\
\text { (postmenopausal) }\end{array}$ & 5 years & $\begin{array}{l}25 / 39 \\
\text { amenorrhea } \\
\text { after } 1 \text { year }\end{array}$ & $\begin{array}{l}0 / 39 \text { after } 12 \\
\text { months and } \\
0 / 29 \text { after } 5 \\
\text { years by } \\
\text { biopsy }\end{array}$ & $11 / 40: N / A$ \\
\hline
\end{tabular}


Table 2. Methodological appraisal for selected studies using the Critical Appraisal Skills Programme checklist ${ }^{15}$

\begin{tabular}{|c|c|c|c|c|c|c|c|c|c|c|c|c|}
\hline Study & $\begin{array}{l}\text { 1. Did } \\
\text { the } \\
\text { study } \\
\text { address } \\
\text { a } \\
\text { clearly } \\
\text { focused } \\
\text { issue? }\end{array}$ & $\begin{array}{l}\text { 2. Was the } \\
\text { assignment } \\
\text { of patients } \\
\text { to } \\
\text { treatments } \\
\text { randomized? }\end{array}$ & $\begin{array}{l}\text { 3. Were } \\
\text { patients, } \\
\text { health } \\
\text { workers, } \\
\text { and study } \\
\text { personnel } \\
\text { blinded? }\end{array}$ & $\begin{array}{l}\text { 4. } \\
\text { Were } \\
\text { the } \\
\text { groups } \\
\text { similar } \\
\text { at the } \\
\text { start } \\
\text { of the } \\
\text { trial? }\end{array}$ & $\begin{array}{l}\text { 5. Aside from } \\
\text { experimental } \\
\text { intervention, } \\
\text { were the } \\
\text { groups } \\
\text { treated } \\
\text { equally? }\end{array}$ & $\begin{array}{l}\text { 6. Were all } \\
\text { the } \\
\text { patients } \\
\text { who } \\
\text { entered } \\
\text { the trial } \\
\text { properly } \\
\text { accounted } \\
\text { for at its } \\
\text { conclusion? }\end{array}$ & $\begin{array}{l}\text { 7. How } \\
\text { large } \\
\text { were the } \\
\text { treatment } \\
\text { effects? }\end{array}$ & $\begin{array}{l}\text { 8. How } \\
\text { precise } \\
\text { were the } \\
\text { treatment } \\
\text { effects? }\end{array}$ & $\begin{array}{l}\text { 9. Can } \\
\text { the } \\
\text { results } \\
\text { be } \\
\text { applied } \\
\text { locally? }\end{array}$ & $\begin{array}{l}\text { 10. Were all } \\
\text { clinically } \\
\text { important } \\
\text { outcomes } \\
\text { considered? }\end{array}$ & $\begin{array}{l}\text { 11. Are } \\
\text { the } \\
\text { benefits } \\
\text { worth } \\
\text { the } \\
\text { harms } \\
\text { and } \\
\text { costs? }\end{array}$ & $\begin{array}{l}\text { Associated } \\
\text { risk of } \\
\text { potential } \\
\text { bias }\end{array}$ \\
\hline $\begin{array}{l}\text { Raudaskoski } \\
(1995)^{10}\end{array}$ & $Y$ & $Y$ & $\mathrm{~N}$ & $Y$ & $Y$ & $Y$ & CT & SP & $Y$ & CT & CT & Low \\
\hline $\begin{array}{c}\text { Antoniou } \\
(1997)^{11}\end{array}$ & $Y$ & $Y$ & $\mathrm{~N}$ & $Y$ & $Y$ & $Y$ & CT & $P$ & $Y$ & CT & $Y$ & Low \\
\hline $\begin{array}{l}\text { Suvanto- } \\
\text { Luukkonen } \\
(1998)^{12}\end{array}$ & $Y$ & $Y$ & $\mathrm{~N}$ & $Y$ & $Y$ & $Y$ & CT & $P$ & $Y$ & CT & CT & Low \\
\hline $\begin{array}{c}\text { Wollter- } \\
\text { Svensson } \\
(2001)^{13}\end{array}$ & $Y$ & $Y$ & $\mathrm{~N}$ & $Y$ & $Y$ & $Y$ & $\mathrm{CT}$ & $P$ & $Y$ & $Y$ & CT & Low \\
\hline $\begin{array}{l}\text { Raudaskoski } \\
(2002)^{14}\end{array}$ & $Y$ & $Y$ & $\mathrm{~N}$ & $Y$ & $Y$ & $Y$ & CT & SP & $Y$ & CT & CT & Low \\
\hline $\begin{array}{c}\text { Boon } \\
(2003)^{15}\end{array}$ & $Y$ & $Y$ & $\mathrm{~N}$ & $Y$ & $Y$ & $Y$ & CT & $P$ & $Y$ & CT & CT & Low \\
\hline $\begin{array}{l}\text { Wildemeersch } \\
(2005)^{16}\end{array}$ & $Y$ & $N$ & $\mathrm{~N}$ & N/A & N/A & $Y$ & CT & NP & $\mathrm{N}$ & CT & CT & High \\
\hline $\begin{array}{l}\text { Wildemeersch } \\
(2007)^{17}\end{array}$ & $Y$ & $\mathrm{~N}$ & $\mathrm{~N}$ & N/A & N/A & $Y$ & CT & NP & $\mathrm{N}$ & CT & CT & High \\
\hline $\begin{array}{c}\text { Hampton } \\
(2005)^{18}\end{array}$ & $Y$ & $N$ & $\mathrm{~N}$ & N/A & N/A & $Y$ & CT & $P$ & $Y$ & $Y$ & CT & High \\
\hline $\begin{array}{c}\text { Varila } \\
(2001)^{19}\end{array}$ & $Y$ & $\mathrm{~N}$ & $\mathrm{~N}$ & $Y$ & N/A & $Y$ & CT & SP & CT & $Y$ & CT & Moderate \\
\hline
\end{tabular}

Abbreviations: $\mathrm{Y}=\mathrm{Yes} ; \mathrm{N}=\mathrm{No} ; \mathrm{CT}=$ Couldn't Tell; $\mathrm{P}=$ Precise; $\mathrm{SP}=$ Somewhat Precise; NP=Not Precise. 
Table 3. Cochrane Risk of Bias Tool ${ }^{16}$

\begin{tabular}{|c|c|c|c|c|c|c|c|c|}
\hline \multirow[t]{2}{*}{ Article } & \multicolumn{2}{|c|}{ Selection Bias } & \multirow{2}{*}{$\begin{array}{l}\text { Performance } \\
\text { Bias } \\
\text { Blinding of } \\
\text { Participants } \\
\text { and } \\
\text { Personnel }\end{array}$} & \multirow{2}{*}{$\begin{array}{c}\begin{array}{c}\text { Detection } \\
\text { Bias }\end{array} \\
\text { Blinding of } \\
\text { Outcome } \\
\text { Assessment }\end{array}$} & \multirow{2}{*}{$\begin{array}{l}\text { Attrition } \\
\text { Bias } \\
\text { Incomplete } \\
\text { Outcome } \\
\text { Data }\end{array}$} & \multirow{2}{*}{$\begin{array}{c}\text { Reporting } \\
\text { Bias }\end{array}$} & \multirow{2}{*}{$\begin{array}{c}\text { Other Bias } \\
\text { Anything } \\
\text { Else, Ideally } \\
\text { Prespecified }\end{array}$} & \multirow{2}{*}{$\begin{array}{l}\text { Total } \\
\text { Low on } \\
\text { Risk of } \\
\text { Bias }\end{array}$} \\
\hline & $\begin{array}{l}\text { Random } \\
\text { Sequence } \\
\text { Generation }\end{array}$ & $\begin{array}{c}\text { Allocation } \\
\text { Concealment }\end{array}$ & & & & & & \\
\hline Andersson $(1992)^{9}$ & Low & Unclear & High & High & Low & Low & Low & $5 / 7$ \\
\hline Raudaskoski (1995) ${ }^{10}$ & Low & Low & High & Low & Low & Low & Low & $6 / 7$ \\
\hline Antoniou $(1997)^{11}$ & Low & Unclear & High & Low & Low & Low & Low & $6 / 7$ \\
\hline Suvanto-Luukkonen $(1998)^{12}$ & High & Unclear & High & Low & Low & Low & Low & $5 / 7$ \\
\hline Wollter-Svensson (2001) & Low & Low & High & Low & Low & Low & Low & $6 / 7$ \\
\hline Raudaskoski (2002) $)^{14}$ & Low & Low & Low & Unclear & High & Low & Low & $6 / 7$ \\
\hline Boon $(2003)^{15}$ & Low & Low & Low & Low & Unclear & Low & Low & $7 / 7$ \\
\hline Wildemeersch $(2005)^{16}$ & High & High & High & High & Low & Low & High & $2 / 7$ \\
\hline Wildemeersch (2007) & High & High & High & High & Low & Low & High & $2 / 7$ \\
\hline Hampton $(2005)^{18}$ & High & High & High & High & Low & Low & Low & $3 / 7$ \\
\hline Varila $(2001)^{19}$ & High & High & High & High & Low & Low & Low & $3 / 7$ \\
\hline
\end{tabular}

Appendix A: Search Strategies

\begin{tabular}{|c|c|}
\hline Database & Search \\
\hline OVID MEDLINE (April 16, 2018) & $\begin{array}{l}\text { 1. Levonorgestrel/ OR Levonorgestrel.it,ab. OR LNG.ti,ab.; } \\
\text { 2. Exp Intrauterine Devices/ OR intrauterine device*.ti,ab. OR intrauterine system*.ti,ab.; } \\
\text { 3. Exp Hormone Replacement Therapy/ OR “Hormone Replacement Therapy".ti,ab. OR } \\
\text { "estrogen replacement therapy".ti,ab. OREstradiol.ti,ab. OR exp Estradiol; } \\
\text { 4. Endometrial.ti,ab. OR exp Endometrium/ OR exp Endometrial Neoplasms/ OR } \\
\text { Endometrial Hyperplasia/; } \\
\text { Combination of: \#1 and \#2 and \#3 and \#4 }\end{array}$ \\
\hline SCOPUS (June 16, 2019) & $\begin{array}{l}\text { 1. Levonorgestrel } \\
\text { 2. Intrauterine Devices } \\
\text { 3. Hormone Replacement Therapy OR Estrogen Replacement Therapy } \\
\text { 4. Endometrial } \\
\text { Combination of: \#1 and \#2 and \#3 and \#4 }\end{array}$ \\
\hline
\end{tabular}

